\title{
QUANTITATIVE EVALUATION OF MICROWAVE IRRADIATION ON SHORT-ROTATION PLANTATION WOOD SPECIES
}

\author{
Sauradipta Ganguly ${ }^{I}$ \\ https://orcid.org/0000-0001-9190-2621 \\ Sanjeet Kumar Hom ${ }^{1, \$}$ \\ https://orcid.org/0000-0003-1289-7161 \\ Sadhna Tripathi ${ }^{1}$ \\ Subhrajit Ghosh ${ }^{1}$ \\ Renu Kanyal ${ }^{1}$ \\ Ajmal Samani ${ }^{1}$
}

\begin{abstract}
The durability of imported timber is a matter of growing concern in the tropical Indian climate, with their refractory nature further adding to the woes with respect to further processing. In the present study, the effect of microwave pre-treatment, exposure time and initial wood moisture content on retention, treatability and cross-sectional anatomical properties of Tectona grandis and Southern yellow pine imported from Ghana and South America were evaluated. Water based preservative copper chrome borate (CCB) of $2 \%$ concentration was used for the study. The experimental study in combination with dip-diffusion method returned with significant improvement in retention of about 5-6 folds more than the control sets in Southern yellow pine and Tectona grandis. Another set of Southern yellow pine and Tectona grandis samples were further treated using a full cell pressure method after microwave, without initial vacuum, which showed similar trends with a 3-4 folds increase in retention over controls. Both experiments returned with significant improvement in the treatability class of Tectona grandis and Southern yellow pine. The anatomical analysis was performed using a light microscope with 5 and 10x magnifications on treated and untreated samples of both Tectona grandis and Southern yellow pine. The outcome of the anatomical study exhibited improvement in vessel diameters in the treated samples of Tectona grandis with a reduction in the degree of occlusion by the presence of tyloses. For Southern yellow pine, checks on micro level and cracks on macro level appeared along with the ray cells and the diameter of the resin canals was substantially expanded which ascertains that microwave pre-treatment ameliorated the flow of fluids in the wood microstructure which improved permeability and resulted in better uptake and penetration.
\end{abstract}

Keywords: Impregnation, microwave, permeability, southern yellow pine, Tectona grandis, treatability, wood durability.

\section{INTRODUCTION}

The threat of climate change is looming over the world due to various anthropogenic activities responsible for emissions of Greenhouse gases (GHG) like carbon dioxide $\left(\mathrm{CO}_{2}\right)$. The increase of carbon in the form of $\mathrm{CO}_{2}$ in the atmosphere for the past few decades has resulted in a steep increase in global mean temperature from $1,8{ }^{\circ} \mathrm{C}$ to $4{ }^{\circ} \mathrm{C}$ (IPCC 2007, Singh et al. 2000). Sustainable forest management and efficient utilisation of the major forest product, i.e. wood, can positively influence $\mathrm{CO}_{2}$ removals by locking the carbon stored in 
harvested wood products and reduce carbon emissions in the global carbon cycle (UNECE 2008). For woody biomass to act efficiently as a carbon sink, the amount of $\mathrm{CO}_{2}$ sequestered in growing forests and the pool of long-lasting wood products must be acceptably larger than the amount of $\mathrm{CO}_{2}$ released by decomposition and combustion (Flugsrud et al. 2001). Due to its natural origin, aesthetic appeal, excellent workability and renewability, wood has gained the attention of the stakeholders and promoted as an eco-friendly construction material in present days across the globe. Recently, wood modification is the most sought-after field in the niche sector of wood science and technology as the dwindling supply of many durable wood species worldwide has compelled industrialists and other patrons to look for alternative species of non-durable nature. Living Forests Model predicted global wood removals of 7,168 billion $\mathrm{m}^{3}$ in 2030 and 11,356 billion $\mathrm{m}^{3}$ in 2050 (WWF 2012) which establishes the demand for woody biomass worldwide. The demand for wood-based panel products and furniture from India is on the rise, due to optimal labour cost and less expensive production process but the gap between demand and supply of raw material is advancing meteorically (Ganguly 2018) and managed

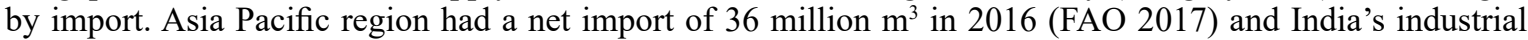
demand for wood was predicted to reach 150 million $\mathrm{m}^{3}$ by 2018 (AHEC 2016). India, being a major importer of round logs and other allied products had an estimated import worth $\$ 2$ billion in the past decade (Sood 2019) with logs estimating to about $74 \%$ of total imported forest products (Montiel 2016, AHEC 2016). Hardwood species of Tectona grandis (TG) and meranti along with softwood species like Southern yellow poplar (SYP) are mostly imported from Malaysia, United States of America, Myanmar and New Zealand (Sood 2014). However, the performance of such imported wood and allied products for several ends uses calls for attention as several imported species perform rather dubiously in the tropical climate of the Indian subcontinent (Sundararaj et al. 2015). This may result in early and frequent replacement of the wood in use which may not be economically and ecologically feasible (Samani et al. 2019). Hence, research on wood modification nowadays in India primarily focuses on several imported and indigenous species of lower durability and enhancing their performance in service (Ganguly and Tripathi 2018, Ganguly et al. 2020, Hom et al. 2020a, Samani et al. 2020, Hom et al. 2020b, Saha et al. 2020).

Additionally, wood in its service span is often exposed to harsh climate (Cheung 2019) and thus, despite being a good building material, it has certain limitations that restrict its extensive use outdoors. Biodegradation of wood in its natural form is elementary but needs to be controlled significantly in service (Kutnik et al. 2014). Wood preservation is the most convenient and efficient method to impart a substantial life span to timber and timber products. However, the extent and execution of this method vary from species to species due to their refractoriness and treatability indices. Poor treatability of wood often results in moderate uptake of treating solutions but meager penetration which fails to address the purpose. To make amends with this nuisance, several wood modification techniques were developed and are being explored to facilitate uptake of treating chemicals. Present day research is primarily focusing on eco-friendly modification practices that limit or reduce excessive use of wood preservatives and frequent replacement of wood in use.

Microwave modification is an eco-friendly technique that reduces energy consumption (Sethy et al. 2016) and aids in several wood processing operations such as seasoning and preservative treatment by significantly improving wood's permeability and preservative uptake, resulting in its effective use for a longer period in service. Previous research on microwave (MW) showed a positive impact on retention and penetration of wood pertaining to moderate and high refractory index with different chemicals and catalysts (Samani et al. 2019, Ganguly and Tripathi 2018, Vinden et al. 2017, Terziev and Daniel 2013, Sethy et al. 2012, Dashti et al. 2012, Torgovnikov and Vinden 2009). Rapid heating of wood microstructure during MW modification results in delamination of the weak anatomical structures like ray cells and parenchyma, resulting in better connectivity of free space in the capillary system and in return an easier fluid flow (Dömény et al. 2014). Using optimum to severe levels of to MW intensity, improvement in permeability in radial and longitudinal direction up to several thousand times in comparison to the untreated samples can be achieved (Liu et al. 2005, Torgovnikov and Vinden 2010, Vinden et al. 2011). Torgovnikov and Vinden (2010) further highlighted the importance of initial moisture content (IMC) of wood prior MW modification. The micro cracks formed in wood during the treatment are basically due to the high-pressure gradient of the vapour, which is generated during MW heating. Green wood performs better in this case in comparison to wood having very low moisture content (MC). MW was explored by Gašparik and Gaff (2013) for wood plasticizing and they also reported the importance of higher MC for this intense process which was later endorsed by Gašparik and Barsik (2014). Further, in some preliminary laboratory trials it has been found that wood having very low MC can be heated upto $170{ }^{\circ} \mathrm{C}$ after MW modification which may result in some chemical modification, slow pyrolysis of the chemical constituents of wood and charring. The char formed by microwave heating has a specific surface area of approximately $450 \mathrm{~m}^{2} / \mathrm{g}$ (Miura et al. 2004). Hence, selecting the modification parameters based on optimum MC is of high importance. 
Anatomical changes after any physical or thermal wood modification is fundamental and well understood. Similarly, MW wood modification also results in a significant change in wood microstructure as reported by several researchers (Hong-Hai et al. 2005, Jiang et al. 2006, Torgovnikov and Vinden 2009, Li et al. 2009, He et al. 2014, Samani et al. 2019) although, in case of moderate modification intensities or species with better structural integrity it may not be evident (Vongpradubchai and Rattandecho 2009).

Based on the above cited literature and findings, the present study was designed to assess the impact of MW modification on retention, treatability and anatomical properties of imported TG and SYP. The species were considered keeping in mind their potential in the context of Indian wood industries in the future and their increasing import to India of late. One refractory hardwood species which is known to have caused hindrance in preservative treatment and one softwood species that was easy to treat were taken to assess the difference of treatment parameters.

\section{MATERIALS AND METHODS}

\section{Sample preparation}

Seasoned planks of SYP and TG imported from South America and Ghana respectively, were procured through local vendors. The study was executed at the Wood Preservation Discipline of Forest Research Institute, Dehradun, India. The planks were subsequently converted into cube samples of side length $3,5 \mathrm{~cm}$ (dimension 3,5 (Longitudinal) x 3,5 (Radial) x 3,5 (Tangential)) cm. Relatively straight grained samples free from any visual abnormalities were selected from the same part of the board and were considered for the study to obtain optimum results and to optimize variability in the data. Samples contained both sap and heartwood portions. The samples were conditioned at $20{ }^{\circ} \mathrm{C} \pm 2{ }^{\circ} \mathrm{C}$ and $85 \% \mathrm{RH}$ in a conditioning chamber for 14 days prior experiment. In total 188 samples (94 each of TG and SYP) were considered for the study (Table 1). Each set of experiments had 10 replicates whereas for anatomical analysis 2 replicates per set were considered. For the oven drying (OD) set, samples of each species were selected from the lot at random and IMC of the samples were determined on an OD basis as per (IS 11215 1991). The IMC (with standard deviation values in parenthesis) of TG was found as $42,0( \pm 0,8) \%$ and that of SYP was $40,8( \pm 1,52) \%$ prior commencement of the experiments.

Table 1: Sample distribution.

\begin{tabular}{|c|c|c|c|}
\hline MW Energy $\left(\mathbf{M J} / \mathbf{m}^{\mathbf{3}}\right)$ & TG & SYP & Total \\
\hline $\mathbf{1 2 0 0}$ & 20 & 20 & 40 \\
\hline $\mathbf{1 3 5 0}$ & 20 & 20 & 40 \\
\hline $\mathbf{1 5 0 0}$ & 20 & 20 & 40 \\
\hline Controls & 20 & 20 & 40 \\
\hline Oven Drying & 10 & 10 & 20 \\
\hline Anatomical Analysis (Untreated/ Control) & 2 & 2 & 4 \\
\hline Anatomical Analysis (Treated at $\left.\mathbf{1 5 0 0} \mathbf{~ M J} / \mathbf{m}^{3}\right)$ & 2 & 2 & 4 \\
\hline Total & $\mathbf{9 4}$ & $\mathbf{9 4}$ & $\mathbf{1 8 3}$ \\
\hline
\end{tabular}

\section{Microwave pre-treatment and preservative impregnation}

MW modification was carried out in a kitchen MW device (Model 30SC3, IFB Industries, India) with frequency $2,45 \mathrm{GHz}$ and maximum output power of $900 \mathrm{~W}$. Treatments were defined based on power and volume of samples and the energies defined in Table 1 were calculated accordingly (Samani et al. 2019). After MW modification, the treated samples were immediately dipped in a test vessel containing a $2 \%$ solution of copper chrome borate (CCB) preservative. Dipping was done for $5 \mathrm{~min}$ and the samples were then taken out of the chamber, dripping preservatives were soaked with a tissue and the mass was recorded. Another set of samples from both species were further subjected to pressure impregnation after MW at $1034212,5 \mathrm{~N} / \mathrm{m}^{2}(10,3$ bar) for $2 \mathrm{~h}$ without initial vacuum, although, a final vacuum for $15 \mathrm{~min}$ was applied. Retention $\left(\mathrm{kg} / \mathrm{m}^{3}\right) \mathrm{was}$ checked for an absorbed quantity of the preservative on a wet weight basis as per (IS 4012001 ) using the following Equation 1: 


$$
\text { Retention }\left(\mathrm{kg} / \mathrm{m}^{3}\right)=\left(\frac{G C \times 10}{V}\right)
$$

Where,

$\mathrm{G}=$ Weight of the treating solution absorbed by sample in $\mathrm{kg}$;

$\mathrm{C}=$ Concentration of treating chemical $(\%)$ and $\mathrm{V}=$ Volume of the specimen, in $\mathrm{m}^{3}$.

\section{Treatability evaluation}

After preservative treatment, specimens were allowed to dry in a controlled chamber with $20{ }^{\circ} \mathrm{C} \pm 2{ }^{\circ} \mathrm{C}$ temperature and $50 \% \pm 2 \%$ relative humidity $(\mathrm{RH})$ for better fixation of the preservative chemicals. After 21 days of conditioning, both treated and untreated specimens were cut into equal halves to detect the presence of copper. The exposed surfaces were sprayed with Chrome Azurol S solution. The spot test exhibited blue color (Figure 1) on cross sections where copper had penetrated and the untreated zones turned red (IS 2753 1991). The percentage area of the treated zone was assessed visually. All four measurements (Figure 1) were averaged to obtain a single penetration value. The penetration data were analyzed as per IS 401 (2001) to determine the treatability class. Treatability class and ICCA was evaluated as per the following representation (Tripathi 2012).

\begin{tabular}{|c|c|c|c|}
\hline $\begin{array}{c}\text { Treatability } \\
\text { Class }\end{array}$ & $\begin{array}{c}\text { Treatability Class as per EN } \\
350 \text { (Nearest Approximation) }\end{array}$ & $\begin{array}{c}\text { ICCA (Impregnated Cross Cut } \\
\text { Area) Average of four sections }\end{array}$ & Demarcation \\
\hline $\mathrm{a}$ & 1 & $65-100 \%$ & Very Permeable \\
\hline $\mathrm{b}$ & 2 & $47-65 \%$ & Permeable \\
\hline $\mathrm{c}$ & 3 & $21-42 \%$ & Moderately permeable \\
\hline $\mathrm{d}$ & 4 & $10-15 \%$ & Impermeable \\
\hline $\mathrm{e}$ & 4 & Nil & Verstant \\
\hline
\end{tabular}

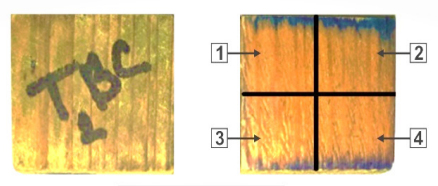

No Impregnation
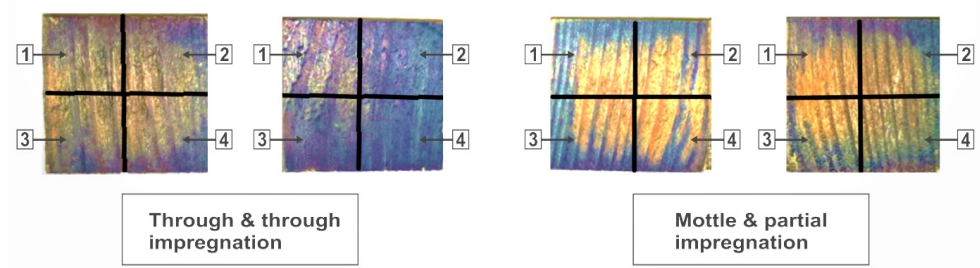

Figure 1: Representative image for treatability evaluation (1,2,3 and 4 represents four sections in each sample). 


\section{Anatomical analysis}

For anatomical analysis two replicates per species from the control sets and two replicates per species from the set of $1500 \mathrm{MJ} / \mathrm{m}^{3}$ were chosen. The extreme sets were selected for better understanding of the changes taking place within wood microstructure. The samples were first checked for the orientation of rays and accordingly a cross sectional cutting pattern for preparation of blocks was decided so that the intersection of growth rings remains as close to $90^{\circ}$ as possible. Samples were cut perpendicular to the axially oriented xylem cells to avoid over- and underestimation of the measured anatomical features. In the present study, only the cross-sectional features were analysed to assess the impact of MW modification. The selected specimens were first sliced into blocks of smaller dimensions $\left(2 \times 2 \times 2 \mathrm{~cm}^{3}\right)$ and were soaked in distilled water for 24 $\mathrm{h}$ at least to avoid damage to cell structures when cutting (Von Arx et al. 2016, Schneider and Gärtner 2013, Gärtner and Schweingruber 2013, Yeung et al. 2015). The samples were further boiled in cycles of $30 \mathrm{~min}$ to prepare them for the microtome. Sections were made of roughly $12 \mu \mathrm{m}-20 \mu \mathrm{m}$ thickness using a Reichert Microtome (Austria, 358926). Heidenhain's haematoxylin and safranin were used for staining the sections and standard laboratory schedule was followed afterwards by passing the section through grades of alcohol $(10 \%$ to $100 \%$ ), and afterwards putting it in xylene and clove oil (50:50) for making permanent slides. Finally, the sections were mounted in Canada balsam. For SYP the resin canal diameters and for TG the vessel diameters were measured. Twenty observations per slide were made and the mean values are reported.

\section{Statistical analysis}

The data were analysed using the SPSS Version 25 package from (IBM 2017) to determine the mean, standard deviation, Pearson correlation and to perform Kruskal-Wallis H test and ANOVA. Mean values were considered to examine significant differences between treatments and Duncan's modified LSD was performed afterwards to examine differences between individual means.

\section{RESULTS AND DISCUSSIONS}

\section{Retention}

Previous studies revealed that improvement of preservative retention in wood is directly proportional to the applied MW energy and results in increase in retention values (Ramezanpour et al. 2015, Ganguly and Tripathi 2018, Samani et al. 2019). MW modified wood samples were dipped in the preservative solution immediately after irradiation so as to simulate the vacuum process in the full cell method and assess its effect in preservative retention. This theory has not been previously reported and hence can be explored further in future to optimise treatment cost. It was found that the steam coming out of the sample through numerous micro cracks formed within the wood, facilitated the preservative uptake and retention. For less refractory SYP, the improvement in retention with only 5 min of dipping returned with retention values of about $7 \mathrm{~kg} / \mathrm{m}^{3}$ for the highest MW energy class which was approximately 9 times more than that of the control set (Figure 2). 


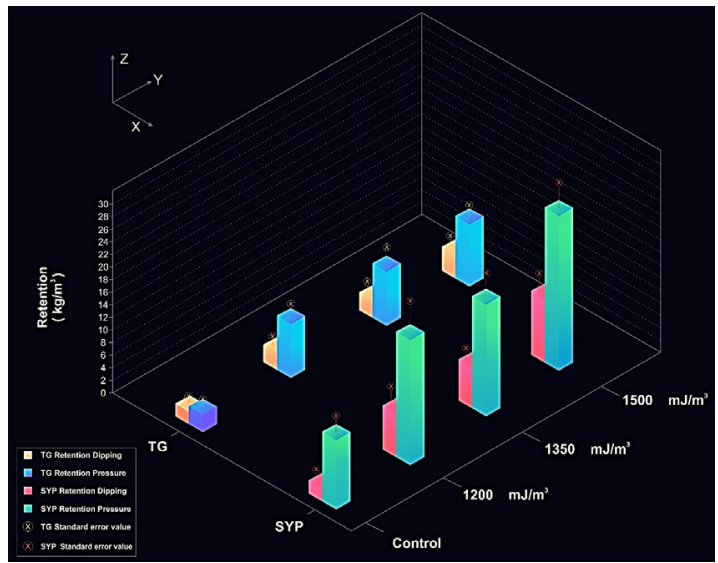

Figure 2: Retention obtained by TG and SYP after different MW treatments and the controls.

Around $6,5 \mathrm{~kg} / \mathrm{m}^{3}$ to 8 Retention $\left(\mathrm{kg} / \mathrm{m}^{3}\right)=\left(\frac{G C \times 10}{V}\right)$ of absorption is recommended for Copper based preser vatives for several above ground applications (IS 4012001 ) and the same was achieved in the present study by dipping of MW modified wood, with minimal energy consumption and without much effort. Such retention values impart adequate protection to the timber when it is not exposed to conditions with extreme humidity or in direct contact with water. For TG, a similar trend was found although with significantly lesser retention value of $2 \mathrm{~kg} / \mathrm{m}^{3}$ after dipping. TG falls under class "e" as per IS 401 (2001) which explains this outcome. However, the retention obtained by TG after 5 min of diffusion treated with highest MW energy was 6 times more than that of the controls (Table 2).

Table 2: Retention values of TG and SYP after diffusion and pressure treatment (standard error within parentheses).

\begin{tabular}{|c|c|c|c|c|}
\hline \multirow{2}{*}{$\begin{array}{l}\text { Treatment } \\
\left(\mathrm{mJ} / \mathrm{m}^{3}\right)\end{array}$} & \multicolumn{2}{|c|}{ Dipping $\left(\mathrm{kg} / \mathrm{m}^{3}\right)$} & \multicolumn{2}{|c|}{ Pressure $\left(\mathrm{kg} / \mathrm{m}^{3}\right)$} \\
\hline & TG & SYP & TG & SYP \\
\hline 1200 & $1,58 \underset{\mathrm{a}, \mathrm{b}}{(+0}, 16)$ & $5,61\left(\frac{ \pm}{\mathrm{c}} 0,93\right)$ & $\left.7,45 \underset{\left(\frac{ \pm}{n}\right.}{n}, 78\right)$ & $18,71 \underset{\mathrm{o}}{ \pm( \pm 3,09)}$ \\
\hline 1350 & $1,55 \underset{\mathrm{a}, \mathrm{b}}{( \pm 0,27)}$ & $5,77 \underset{\mathrm{c}}{ \pm}+0,36)$ & $7,51(\underset{\mathrm{n}}{ \pm} 0,55)$ & $20,62 \underset{\mathrm{o}}{( \pm 1,26)}$ \\
\hline 1500 & $2,18\left(\frac{+0}{\mathrm{~b}}, 20\right)$ & $7,17\left(\frac{+0,66)}{\mathrm{d}}\right.$ & $8,67 \underset{\mathrm{n}}{( \pm 0,24)}$ & $23,91 \underset{\mathrm{p}}{( \pm 2,2)}$ \\
\hline Control & $0,35 \underset{\frac{a}{a}}{( \pm 0,02)}$ & $0,78 \underset{\mathrm{a}}{( \pm 0,05)}$ & $1,59 \underset{\mathrm{m}}{( \pm 0,09)}$ & $9,94\left(\frac{+0}{\mathrm{n}}, 53\right)$ \\
\hline
\end{tabular}

Different alphabets denote different homogeneous subgroups as per Duncan Analysis. Duncan Analyses were done separately for pressure and diffusion and the results are represented with a,b,c and $d$ being the subsets for diffusion retention and $m, n, o$ and $p$ being the subsets for pressure retention.

Dipping as well as pressure treatment resulted in statistically improved retention of all the treatments when compared to the controls as revealed by Duncan Subset in both the species (Table 2) which establishes the overall efficacy of the study. Similar trends regarding uptake of water or treating solutions were observed by Treu and Gjolsjo (2008) and Hong-Hai et al. (2005) after MW pre-treatment. With additional pressure, the impregnation values improved further with SYP showing retention values of $19 \mathrm{~kg} / \mathrm{m}^{3}$ to $24 \mathrm{~kg} / \mathrm{m}^{3}$ which was 2-2,5 folds more than that achieved by non-MW modified controls. Both the treatments yielded statistically significant outcomes (Table 3). Wood obtained from fast grown plantation softwood like SYP usually has a 
high proportion of juvenile wood and less of heartwood hence low natural durability (Hill 2007) resulting in restricted uses in extremely harsh climatic conditions or outdoors which can be alleviated by this method. SYP, treated with MW and impregnated with preservative after pressure, can be explored in severe climatic conditions and may exhibit durability beyond its otherwise specified period of 60 months (IS 401, 2001) which may result in its frequent use. Indigenous or imported TG is considered a durable species and falls under durability Class 1 (IS 401, 2001) while plantation grown TG sapwood is moderately durable and falls under Class 3. Under extreme exposure, not much protection is needed for TG timber, however, added retention of preservative is always a plus to enhance the durability of wood in service. TG samples treated with highest MW energy exhibited 4 times more retention values in comparison to the controls. Highest MW exposure yielded retention of approximately $9 \mathrm{~kg} / \mathrm{m}^{3}$ for TG which may surely be enough to improve its durability substantially beyond the stipulated time range of 120 months in natural form. Table 3 exhibits that the retention of treating chemicals after diffusion or pressure impregnation, has a strong positive correlation with MW irradiation energy. The coefficient of determination $\left(\mathrm{r}^{2}\right)$ observed was 0,516 and 0,378 for SYP while 0,491 and 0,573 for TG with regards to dipping and pressure type of preservative treatment respectively, indicating the same. Enhanced retention corresponds to enhanced durability which means less frequent replacement of harvested wood products and thus a sustainable use of the woody biomass, locking the carbon stored.

Table 3: Pearson's coefficient of determination ( $\mathrm{r}^{2}$ values) between the treatments for SYP and TG $(p \leq 0,01)$.

\begin{tabular}{|c|c|c|c|c|}
\hline \multirow{2}{*}{ Treatment } & \multicolumn{2}{|c|}{ SYP } & \multicolumn{2}{c|}{ TG } \\
\cline { 2 - 5 } & Dipping & Pressure & Dipping & Pressure \\
\hline MW modification at different \\
$\begin{array}{c}\text { energy level } \\
\text { neryyyyy}\end{array}$ & $\begin{array}{c}0,516 \\
\left(0,718^{* *}\right)\end{array}$ & $\begin{array}{c}0,378 \\
\left(0,615^{* *}\right)\end{array}$ & $\begin{array}{c}0,491 \\
\left(0,701^{* *}\right)\end{array}$ & $\begin{array}{c}0,573 \\
\left(0,757^{* *}\right)\end{array}$ \\
\hline
\end{tabular}

Values in parenthesis represent Pearson's correlation ( $\mathrm{r}$ value)

**Correlation is significant at the 0,01 level (2-tailed).

\section{Treatability}

Inspection was carried out visually after MW modification which highlighted that the control specimens of TG were highly refractory in nature and belonged to class "e" with very little or practically no impregnation. SYP controls were relatively more permeable and fell in class "d" Treatability class of both the species improved significantly after the MW pre-treatment with highly refractory TG being elevated to class "a" from class "e" and SYP to class "a" from class "d" (Figure 4). Tarmian et al. (2020) have mentioned that treatability and permeability are strongly correlated and the finding of this study further substantiates their claim as after MW treatment the reduction in the occlusion level in TG and checks and cracks formed in the microstructure of SYP might have positively influenced the permeability of the species (He et al. 2014, Wang et al. 2014) resulting in an easier flow of treating chemicals. The mean ICCA obtained for each set was statistically analyzed using the Kruskal Wallis nonparametric ranking test to assess the significance of MW modification energy. The impact of MW irradiation was statistically evident on treatability and penetration of both the species (Table 4) and the improvements in treatability obtained were in line with similar findings by Ramezanpour et al. 2015 and Samani et al. 2019 where highest treatability corresponded to the highest MW energy class (Figure 3 ). 


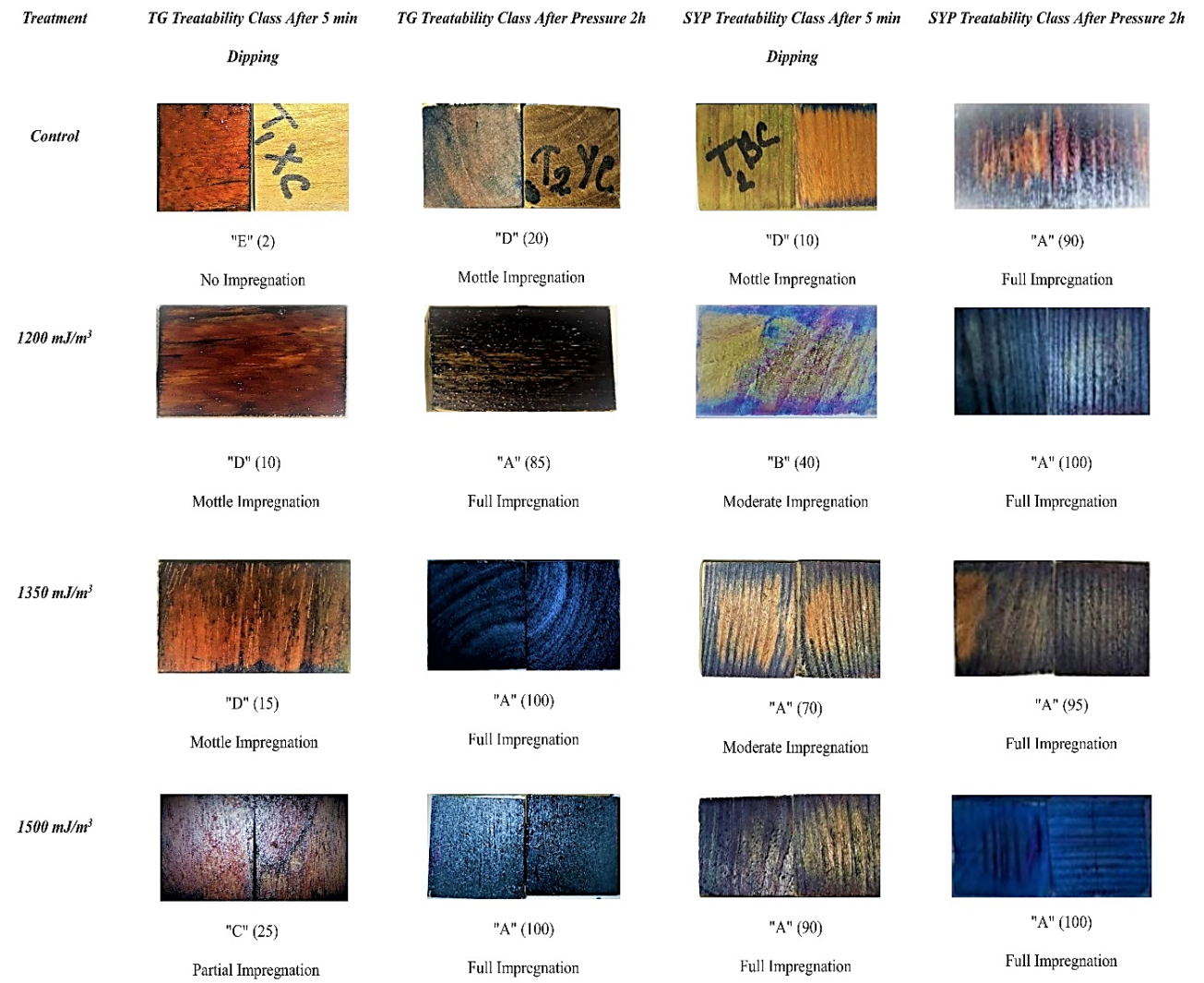

Figure 3: Treatability Evaluation of TG and SYP after Dipping and Pressure Treatment. (Values in Parentheses denote mean penetration percentage/ ICCA of each set consisting 10 replicates. Blue color indicates the presence of Copper. Corresponding photos represent each set).

Table 4 shows a significant difference of MW modification energy on treatability as p value is less than 0,05 . A post hoc independent sample test (Figure 4) shows that in case of TG, dipping and pressure impregnation of preservative shows significant difference in treatability. Although, the effect of MW modification was non-significant between different MW energy levels for both dipping and pressure treatments. For SYP, the effect of different MW energy levels on treatability for dipping was significant statistically, while pressure treatment showed no statistical difference(Figure 4). It is also pertinent to mention that, Chromium based preservatives might not perform well in terms of treatability evaluation due to the high reaction rate of chromium with wood and relatively longer (24h) fixation time (Morris et al. 2002, Cooper and Morris 2007) which might have also resulted in the poor retention and treatability of the control samples after subsequent dipping of $5 \mathrm{~min}$. This enhanced treatability of both hard and soft wood after MW pre-treatment can be of particular interest for several wood processing parameters such as coating, pulping, bonding of adhesives and chemical modification of timber (Tarmian et al. 2020) where homogeneity in treatment is a must and can be ensured. 
Table 4: Kruskal- Wallis H test for treatability.

\begin{tabular}{|c|c|c|}
\hline Test Statistics a,b & & \\
\hline & TG & SYP \\
\hline Kruskal-Wallis H & 73,666 & 71,564 \\
\hline df & 7 & 7 \\
\hline Asymp. Sig. & 0,000 & 0,000 \\
\hline
\end{tabular}

a Kruskal Wallis Test; b Grouping Variable: Treatment.

\section{Anatomical analysis}

The enhanced treatability and retention were substantiated further by the finding of anatomical cross-sectional analysis of treated and untreated specimens of both the species. For TG, refractoriness can be attributed to the degree of occlusion in its vessels which is often fully or partially choked with tyloses (Figure 5A). The presence of these vessel inclusions in teak, often makes it extremely difficult to treat with preservatives prior to use. MW pre-treatment, because of its typical wood modification acumen, can prove to be an efficient solution to these hindrances. It can be hypothesized that the high steam pressure with the fast-moving steam, generated within wood during the process, may flush out all such inclusions completely or partially from the core to the periphery. These pressure gradients developed during the treatment, can improve the effective vessel diameter (Samani et al. 2019) and aid in fluid and vapour flow through the entire volume of the test specimen in all three major axes (Torgovnikov and Vinden 2009). It was found that the effective mean vessel diameter (EMVD) of TG samples (Figure 5J) improved significantly $(\mathrm{P} \leq 0,05)$ in comparison to the untreated samples (Figure 5I). EMVD of the treated samples was recorded (standard error values in parenthesis $)$ as $259( \pm 5,75) \mu \mathrm{m}$ whereas the same for the controls were 186,5 $( \pm 6,17) \mu \mathrm{m}$. Apart from this obvious change (Figure 5J), the anatomical appearance changed drastically with minor cracks (Figure 5B) and significantly clearer vessels (Figure 5F), free from vessel inclusion after MW. Anatomy of SYP also altered due to the treatment with resin canals showing a clearer appearance and visible cracks and checks along the weak ray cells which might have facilitated the fluid flow. Mean canal diameter of untreated controls were 112,5 $( \pm 6,17) \mu \mathrm{m}$ which was statistically different from $266,25( \pm 5,77) \mu \mathrm{m}$ for the modified set. The results of the anatomical study were in conformity with Weng et al. 2020 and He et al. 2014.
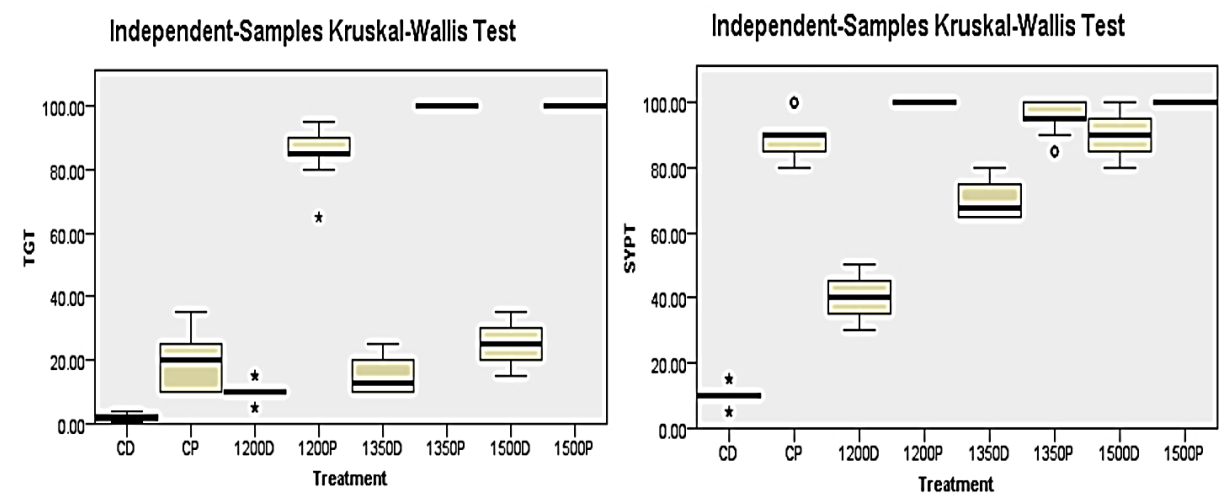

Figure 4: Kruskal-Wallis analysis for treatability of TG and SYP $(\mathrm{TGT}=\mathrm{TG}$ Treatability, SYPT $=$ SYP Treatability, $\mathrm{D}=$ Dipping, $\mathrm{P}=$ Pressure, $\mathrm{C}=$ Control, 1200, 1300, $1500=$ MW Energy in $\mathrm{mJ} / \mathrm{m}^{3}$ ). 


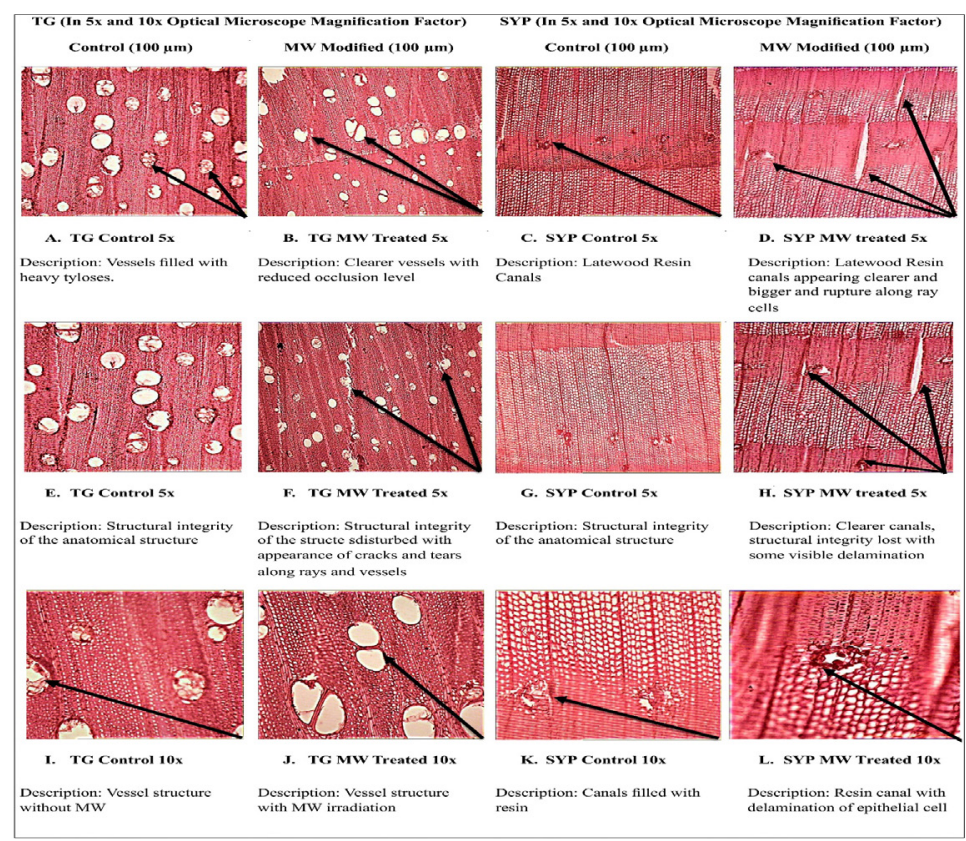

Figure 5: Anatomical Structure of MW treated and untreated samples of TG and SYP. (A-B-C-D-E-F-G-H-I-J-K-L).

\section{CONCLUSIONS}

MW wood modification is a potential tool to improve the treatability and permeability of several timber species of non-durable and refractory nature, ensuring their longevity and reducing frequent replacement in service. This maintains the carbon storage potential of harvested wood products and increases the possibilities of carbon dioxide sequestration by plantation. In addition, this method holds promise to reduce treatment time and energy consumption for the otherwise extensive wood processing techniques which can be immensely profitable and of particular interest for the small-scale industrialists. This process also ensures higher retention in relatively shorter exposure times which is established in the present study with water based preservative CCB. The anatomical structure of both soft and hardwood showed some delamination although the magnitude of the distortion varied between species mainly due to their inherent structural integrity. This phenomenon in particular must be considered prior to expose MW modified wood for extensive structural application as this may lead to some reduction in strength. However, this reduction in strength may be cosmetic if the treatment parameters are optimised.

\section{ACKNOWLEDGEMENTS}

The lead author is thankful to Ms. Deepa Bisht, Dr. Vidisha Kandpal, Dr. Prachi Gupta from Wood Anatomy Discipline and Mr. Deepak Sharma, FRIDU, Dehradun for their support during the execution of the study.

\section{REFERENCES}

American Hardwood Export Council. 2016. India Wood Sector Market Study. AHEC: Karnataka, India. $44 \mathrm{p}$.

Bureau of Indian Standards. IS. 1991. Moisture Content of Timber and Timber Products-Methods for Determination. IS 11215. 1991. Manak Bhawan, New Delhi, India. https://archive.org/details/gov.in.is. 11215.1991 
Bureau of Indian Standards. IS. 1991. Methods for estimation of preservatives in treated timber and in treating solutions. IS 2753. 1991. Manak Bhawan, New Delhi, India. https://law.resource.org/pub/in/bis/S03/ is.2753.1.1991.pdf

Bureau of Indian Standards. IS. 2001. Preservation of timber code of practice. IS 401. 2001. Manak Bhawan, New Delhi, India. https://archive.org/details/gov.in.is.401.2001

Cheung, K.C.K. 2019. Wooden Structures. Ref Modul Mater Sci Mater Eng 1: 1-14. https://doi.org/10.1016/B978-0-12-803581-8.02225-6

Cooper, P.; Morris, P. 2007. Challenges in treating Canadian species. In Proceedings of 28th annual general meeting. Canadian wood preservation association, Quebec, Canada. pp 9-20. https://www.cwpa.ca/ publications/\#tab-2007-tab

Dashti, H.; Tarmian, A.; Faezipour M.; Hedjazi, S.; Shahverdi, M. 2012. Effect of microwave radiation and pre-steaming treatments on the conventional drying characteristics of fir wood (Abies alba L.). Lignocellulose 1: 166-173. https://n9.cl/kmkq7

Dömény, J.; Koiš, V.; Dejmal, A. 2014. Microwave radiation effect on Axial Fluid Permeability in false heartwood of Beech (Fagus sylvatica L.). BioResources 9(1): 372-380. https://ojs.cnr.ncsu.edu/index.php/BioRes/article/view/4619

European Standard. 2016. Durability of wood and wood-based products - Testing and classification of the durability to biological agents of wood and wood-based materials. EN 350. 2016. https://standards.iteh.ai/ catalog/standards/cen/b02d18a7-87ce-4a20-84c7-c0de641a2780/en-350-2016

Food and Agriculture Organization. 2017. Global Forest Products- Facts and Figures 2016. Food and Agriculture Organization of the United Nations: Rome. http://www.fao.org/3/I7034EN/i7034en.pdf

Flugsrud, K.; Hoem, B.; Kvingedal, E.; Rypdal, K. 2001. Estimating the net emission of $\mathrm{CO}_{2}$ from harvested wood products: A comparison between different approaches. Norwegian Pollution Control Authority: Norway

Ganguly, S. 2018. Conserving wood biodiversity with the help of wood science and technology. Int Res $J$ Environmental Sci 7(11): 42-44. http://www.isca.in/IJENS/Archive/v7/i11/6.ISCA-IRJEvS-2018-065.pdf

Ganguly, S.; Tripathi, S. 2018. Study on Effect of Microwave Treatment on Wood Permeability and Preservative Retention in Imported Timber. J Agroecology Nat Res Management 5(1): 34-40. https://www. krishisanskriti.org/Publication.html

Ganguly, S.; Tripathi, S.; Tiwari, P.; Sumi, A.; Kanyal, R. 2020. Screening of Azadirachta indica seed oil against sap-stain and mould fungi in imported Tectona grandis and Southern Yellow Pine wood through fumigation. J Trop For Sci 32(2): 114-124. https://doi.org/10.26525/jtfs32.2.114

Gärtner, H.; Schweingruber, F.H. 2013. Microscopic Preparation Techniques for Plant Stem Analysis. Remagen: Kessel Publishing House. www.forestrybooks.com

Gašparik, M.; Barsik, S. 2014. Effect of Plasticizing by Microwave Heating on Bending Characteristics of Beech Wood. Bioresources 9(3): 4808-4820. https://bioresources.cnr.ncsu.edu/resources/effect-of-plasticizing-by-microwave-heating-on-bending-characteristics-of-beech-wood/

Gašparik, M.; Gaff, M. 2013. Changes in temperature and moisture content in beech wood plasticized by microwave heating. Bioresources 8(3): 3372-3384. https://ojs.cnr.ncsu.edu/index.php/BioRes/article/ view/3974

He, S.; Lin, L.; Fu, F.; Zhou, Y.; Fan, M. 2014. Microwave treatment for enhancing the liquid permeability of Chinese fir. Bioresources 9(2): 1924-1938. https://bioresources.cnr.ncsu.edu/resources/microwave-treatment-for-enhancing-the-liquid-permeability-of-chinese-fir/

Hill, C.A.S. 2007. Acetylated wood - the science behind the material. https://www.accoya.com/app/uploads/2020/04/Acetylated-Woods-Callum Hill.pdf 
Hom, S.K.; Ganguly, S.; Bhoru, Y.U.; Samani, A. 2020a. Effect of chemical modification on dimensional stability of Pinus radiata D. Don using acetic anhydride. J For Sci 66: 208-217. https://doi.org/10.17221/13/2020-JFS

Hom, S.K.; Ganguly, S.; Samani, A; Tripathi, S. 2020b. Improvement in fire retardancy with double-step chemical modification on Pinus radiata D. Don using dimethyl methylphosphonate with propylene oxide and maleic anhydride. Int Wood Prod J 11(3): 138-145. https://doi.org/10.1080/20426445.2020.17 65624

Hong-Hai, L.; Qing-Wen, W.; Lin, Y.; Tao, J.; Ying-Chun, C. 2005. Modification of larch wood by intensive microwave irradiation. J For Res 16(3): 237-240. https://doi.org/10.1007/BF02856823

IBM. 2017. SPSS Modeler. SPSS V25. SPSS Inc: Chicago, USA

Intergovernmental Panel on Climate Change. 2007. Renewable energy sources and climate change mitigation. IPCC: Mauritius. https://www.ipcc.ch/report/renewable-energy-sources-and-climate-change-mitigation/

Jiang, T.; Zhou, Z.F.; Wang, Q.W. 2006. Effects of intensive microwave irradiation on the permeability of larch wood. Sci Silv Sin 42(11): 87-92. http://d.wanfangdata.com.cn/periodical/lykx200611016

Kutnik, M.; Suttie, E.; Brischke, C. 2014. European standards on durability and performance of wood and wood-based products-Trends and challenges. Wood Mater Sci Eng 9: 122-133. https://doi.org/10.1080/17 480272.2014.894574

Li, J.; Zhang, L.P.; Peng, F.; Bian, J.; Yuan, T.Q.; Xu, F.; Sun, R.C. 2009. Microwave-assisted solvent-free acetylation of cellulose with acetic anhydrideinthepresence ofiodine as a catalyst. Molecules 14(9): 3551-3566. https://doi.org/10.3390/molecules14093551

Liu, H.H.; Wang, Q.W.; Yang, L.; Jiang, T.; Cai, Y.C. 2005. Modification of larch wood by intensive microwave irradiation. J For Res 16 (3): 237-240. https://doi.org/10.1007/BF02856823

Miura, M.; Kaga, H.; Sakurai, A.; Takahashi, K. 2004. Rapid pyrolysis of wood block by microwave heating. J Anal Appl Pyrolysis 71(1): 187-199. https://doi.org/10.1016/S0165-2370(03)00087-1

Montiel, J.P.Q. 2016. Analysis of India as a Market Area for Sawn wood. Thesis. Department of Forest Sciences, University of Helsinki, Finland. https://helda.helsinki.fi/handle/10138/161658

Morris, P.I.; McFarling, S.M.; Zahora, A.R. 2002. Treatability of refractory species with amine and amine/ammoncal formulations of ACQ. For Prod J 52(10): 37-42. https://ehu.idm.oclc.org/login?url=https:// www.proquest.com/scholarly-journals/treatability-refractory-species-with-amine/docview/214635127/ se-2?accountid $=17248$

Ramezanpour, M.; Tarmian, A.; Taghiyari, H.R. 2015. Improving impregnation properties of Fir wood to acid copper chromate (ACC) with microwave pretreatment. iforest 8(1): 89-94. https://doi.org/10.3832/ ifor1119-007

Saha, S.; Ganguly, S.; Tripathi, S. 2020. Improving preservative retention and penetration of imported Tectona grandis using microwave treatment. Pro Ligno 16 (3): 44-52. http://www.proligno.ro/ro/ articles/2020/3/SAHA_Final.pdf

Samani, A.; Ganguly, S.; Kanyal, R.; Tripathi, S. 2019. Effect of microwave pre-treatment on preservative retention and treatability of Melia composita wood. J For Sci 65: 391-396. https://doi.org/10.17221/39/2019JFS

Samani, A.; Hom, S.K.; Bhoru, Y.U.; Ganguly, S. 2020. Dimensional Stability of Wood Modified by Citric Acid. Ind For 146 (5): 455-458. https://hrcak.srce.hr/index.php?show=clanak\&id_clanak_jezik=54710

Schneider, L.; Gärtner, H. 2013. The advantage of using a starch based non-Newtonian fluid to prepare micro sections. Dendrochronologia 31(3): 175-178. https://doi.org/10.1016/j.dendro.2013.04.002 
Sethy, A.K.; Torgovnikov, G.; Vinden, P.; Przewloka, S. 2016. Moisture conditioning of wood using a continuous microwave dryer. Dry Technol 34(3): 318-323. https://doi.org/10.1080/07373937.2015.1052502

Sethy, A.K.; Vinden, P.; Torgovnikov, G.; Militz, H.; Mai, C.; Kloeser, L.; Przewloka, S. 2012. Catalytic Acetylation of Pinus radiata (D. Don) with Limited Supply of Acetic Anhydride Using Conventional and Microwave Heating. $J$ Wood Chem Technol 32(1): 1-11. https://doi.org/10.1080/02773813.2011.573121

Singh, T. P.; Varalakshmi, V.; Ahluwalia, S. K. 2000. Carbon Sequestration through Farm Forestry: Case from India. Ind For 126(12): 1257-1264. https://www.cabdirect.org/cabdirect/abstract/20013044895

Sood, D. 2014. Gain Report: Wood and Wood Products in India 2014. Gain Report IN4049. USDA Foreign Agricultural Service. Global Agricultural Information Network: New Delhi. https://apps.fas.usda. gov/newgainapi/api/report/downloadreportbyfilename?filename=Wood $\% 20$ and $\% 20$ Wood $\% 20$ Products $\% 20$ in\%20India\%202014_New\%20Delhi_India_6-24-2014.pdf

Sood, D. 2019. Wood and Wood Products Update 2019. GAIN Report IN 9033. USDA Foreign Agricultural Service. Global Agricultural Information Network: New Delhi. https://apps.fas.usda.gov/newgainapi/api/report/downloadreportbyfilename?filename=Wood $\% 20$ and $\% 20$ Wood $\% 20$ Products $\% 20$ Update\%202019_New\%20Delhi_India_4-17-2019.pdf

Sundararaj, R.; Shanbhag, R.R.; Nagaveni, H.C.; Vijayalakshmi, G. 2015. Natural durability of timbers under Indian environmental conditions-an overview. Int Biodeterior Biodegradation 103: 196-214. https://doi.org/10.1016/j.ibiod.2015.04.026

Tarmian, A.; Tajrishi, Z.I.; Oladi, R.; Efhamisisi, D. 2020. Treatability of wood for pressure treatment processes: a literature review. Eur J Wood Prod 78: 635-660. https://doi.org/10.1007/s00107-020-01541-w

Terziev, N.; Daniel, G. 2013. Application of high frequency treatments for improvedpermeability of Norway spruce (Picea abies Karst.) wood. In Wood the Best Material for Mankind. Kudela, J.; Babiak, M. eds, Zvolen: Arbora Publishers: 15-19. https://iaws-web.org/files/file/Zborník\%202012.pdf

Torgovnikov, G.; Vinden, P. 2009. High-intensity microwave wood modification for increasing permeability. For Prod J 59 (4): 84-92. https://www.cabdirect.org/cabdirect/abstract/20093215187

Torgovnikov, G.; Vinden, P. 2010. Microwave wood modification technology and its applications. For Prod J 60(2): 173-182. https://doi.org/10.13073/0015-7473-60.2.173

Treu A.; Gjolsjo, S. 2008. Spruce impregnation, finally a breakthrough by means of microwave radiation. In Proceedings of the 4th Meeting of the Nordic Baltic Network in Wood Material Science \& Engineering (WSE). Riga (Latvia) 13-14 Nov 2008. Horsholm, SNS-Nordic Forest Research Co-operation Committee, Copenhagen University: 42-48. https://agris.fao.org/agris-search/search.do?recordID=LV2009000588

Tripathi, S. 2012. Treatability evaluation of meranti with ZiBOC and CCA. Int Wood Prod J 3(2): 70-76. https://doi.org/10.1179/2042645311Y.0000000021

United Nations Economic Commission for Europe. UNECE. 2008. Harvested Wood Products in the Context of Climate Change Policies. Geneva Timber and Forest Discussion Papers 55, United Nations: Geneva.

Vinden, P.; Torgovnikov, G.; Hann, J. 2011. Microwave modification of radiata pine railway sleepers for preservative treatment. Eur J Wood Prod 69: 271-279. https://doi.org/10.1007/s00107-010-0428-8

Vinden, P.; Torgovnikov, G.; Sethy, A.K. 2017. Conveyor Belt Pressure Impregnation of Wood. In Wood is Good. Pandey, K.; Ramakantha, V.; Chauhan, S; Kumar A. (eds) Springer: Singapore. https://doi.org/10.1007/978-981-10-3115-1_21

Von Arx, G.; Crivellaro, A.; Prendin, A.L.; Čufar, K.; Carrer, M. 2016. Quantitative Wood Anatomy-Practical Guidelines. Front Plant Sci 7:781. https://doi.org/10.3389/fpls.2016.00781

Vongpradubchai, S.; Rattanadecho, P. 2009. The microwave processing of wood using a continuous microwave belt drier. Chem Eng Process 48(5): 997-1003. https://doi.org/10.1016/j.cep.2009.01.008 
Wang, D.; Peng, L.; Zhu, G.; Fu, F.; Zhou, Y.; Song, B. 2014. Improving the Sound Absorption Capacity of Wood by Microwave Treatment. Bioresources 9 (4): 7504-7518. https://bioresources.cnr.ncsu.edu/ resources/improving-the-sound-absorption-capacity-of-wood-by-microwave-treatment/

Weng, X.; Zhou, Y.; Fu, Z.; Gao, X.; Zhou, F.; Fu, F. 2020. Effects of Microwave Treatment on Microstructure of Chinese Fir. Forests 11(7): 772. https://doi.org/10.3390/f11070772

World Wide Fund. 2012. Forest and wood products. In: WWF Living forest report. Chapter 3. https://d2ouvy59p0dg6k.cloudfront.net/downloads/living_forests_report_ch4_forest_products.pdf

Yeung, E.C.T.; Stasolla, C.; Sumner, M.J.; Huang, B.Q. 2015. Plant Microtechniques and Protocols. Springer: New York, NY. https://link.springer.com/book/10.1007/978-3-319-19944-3 